University of Nebraska - Lincoln

DigitalCommons@University of Nebraska - Lincoln

2004

\title{
The History of Recent Limnological Changes and Human Impact on Upper Klamath Lake, Oregon
}

\author{
J. Platt Bradbury \\ 5784 Horseradish Gulch, Golden, C0 80403, USA \\ Steven M. Colman \\ US Geological Survey, 384 Woods Hole Rd., Woods Hole, MA 02543, USA \\ Richard L. Reynolds \\ US Geological Survey, Box 25046 Federal Center, Denver, CO 80225, USA
}

Follow this and additional works at: https://digitalcommons.unl.edu/usgsstaffpub

Part of the Earth Sciences Commons

Bradbury, J. Platt; Colman, Steven M.; and Reynolds, Richard L., "The History of Recent Limnological Changes and Human Impact on Upper Klamath Lake, Oregon" (2004). USGS Staff -- Published Research. 281.

https://digitalcommons.unl.edu/usgsstaffpub/281

This Article is brought to you for free and open access by the US Geological Survey at DigitalCommons@University of Nebraska - Lincoln. It has been accepted for inclusion in USGS Staff -- Published Research by an authorized administrator of DigitalCommons@University of Nebraska - Lincoln. 
This article is a U.S. government work, and is not subject to copyright in the United States.

\title{
The history of recent limnological changes and human impact on Upper Klamath Lake, Oregon ${ }^{\star}$
}

\author{
J. Platt Bradbury ${ }^{1}$, Steven M. Colman ${ }^{2 *}$ and Richard L. Reynolds ${ }^{3}$ \\ ${ }^{1} 5784$ Horseradish Gulch, Golden, CO 80403, USA; ${ }^{2}$ US Geological Survey, 384 Woods Hole Rd., Woods \\ Hole, MA 02543, USA; ${ }^{3}$ US Geological Survey, Box 25046 Federal Center, Denver, CO 80225, USA; \\ *Author for correspondence (e-mail: scolman@usgs.gov)
}

Received 23 October 2002; accepted in revised form 2 July 2003

Key words: Diatoms, Eutrophication, Limnology, Sediment magnetic properties, Tephra, Upper Klamath Lake

\begin{abstract}
Hypereutrophic Upper Klamath Lake has been studied for almost 50 years to evaluate the nature, cause, and effects of its very productive waters. Mitigation of undesirable effects of massive cyanobacterial blooms requires understanding their modern causes as well as their history. Knowledge of the pre-settlement natural limnology of this system can provide guidelines for lake restoration and management of land and water use strategies to maximize the benefits of this aquatic resource. This investigation uses a paleolimnological approach to document the nature and chronology of limnological and biological changes in Upper Klamath Lake for the past 200 years, covering the time when the lake was first described until today. A 45-cm gravity core, dated by ${ }^{210} \mathrm{~Pb}$ and diatom correlations, was analyzed for diatoms, pollen, akinetes (resting spores) of the cyanobacterium Aphanizomenon flos-aquae, reworked tephra shards, and sediment magnetic characteristics. Pollen profiles show little vegetation change during this time. In contrast, diatoms indicative of increased nutrient fluxes ( $\mathrm{P}$ and $\mathrm{Si}$ ) increase moderately, coinciding with the settlement of the region by Euro-Americans. Numerous settlement activities, including draining of lake-margin marshes, upstream agriculture and timber harvest, road construction, and boat traffic, may have affected the lake. Magnetic properties and reworked tephra suggest riparian changes throughout the basin and increased lithogenic sediment delivery to the lake, especially after 1920 when the marshes near the mouth of the Williamson River were drained and converted to agricultural and pasture land. Drainage and channelization also decreased the ability of the marshes to function as traps and filters for upstream water and sediments. Akinetes of Aphanizomenon flos-aquae record progressive eutrophication of Upper Klamath Lake beginning in the 20th century and particularly after 1920 when lake-margin marsh reclamation more than doubled. The coincidence of limnological changes and human activities following European settlement suggests a major impact on the Upper Klamath Lake ecosystem, although ascribing specific limnological changes to specific human activities is difficult.
\end{abstract}

\footnotetext{
^ This is the third in a series of eight papers published in this special issue, resulting from paleoenvironmental studies in the Upper Klamath Lake Basin. These studies were conducted by the US Geological Survey and its collaborators as part of a paleoclimate research effort called the Correlation of Marine and Terrestrial Records Project. Steven M. Colman served as guest editor of this special issue.
}

\section{Introduction \\ Background}

The general aridity of western North America has placed significant demands on existing water 
resources for irrigation, domestic and recreational use, and for habitats essential to both aquatic and terrestrial wildlife. Before European settlement, Upper Klamath Lake was utilized by indigenous Modoc and Klamath inhabitants of the region as a source of food, shelter and transportation (e.g., Frémont 1845; Grayson 1976), but it is unlikely their impact changed the lake substantially from its natural state. During one of the first Bureau of Reclamation projects (1905), some of the shallow lakes and marshes of the Klamath basin were diked and drained for agriculture. A variety of other land-use changes related to agriculture and ranching followed. Subsequent historical observations of the lake comment on its productive waters and occasional blooms of nuisance algae. Nevertheless, opinions about the natural character of Upper Klamath Lake and causes of its present hypereutrophic state range widely (Grayson 1976; Bortleson and Fretwell 1993; Snyder and Morace 1997). In 1995, a selected bibliography of waterrelated research on Upper Klamath Lake contained 165 papers (Brownell and Rinallo 1995), nearly 80 percent 'gray' literature. Because of potential conflict in water use, water quality management for the lake is a subject of considerable discussion (Boyd et al. 2002). On-going monitoring (e.g., Risley and Laenen 1998) and limnological studies (Eilers et al. in press) are in progress.

This paper follows on a suggestion in one early report (Phinney et al. 1959) that the sedimentary record of Upper Klamath Lake be examined for a historical perspective on its limnology and the possible impacts that European Americans may have had on the lake. From preliminary observation of a sediment core, Phinney et al. (1959) implied that the nuisance cyanobacteria blooms (Aphanizomenon flos-aquae) were a recent phenomenon, but they were reluctant to suggest human water- and landuse strategies as probable causes for hypereutrophication. The paleolimnological study of the Phinney et al. core was never completed. However, the logic of their suggestion stimulated our study to document the nature and timing of limnological and biological changes in Upper Klamath Lake over the past 200 years by a multi-proxy examination of a well-dated sediment core. The historical record offers a way to help understand the relation between land-use and limnology and it can provide baselines for lake restoration efforts.

\section{Setting}

The geological, climatological, and limnological setting of Upper Klamath Lake (Figure 1) are discussed in detail by Colman et al. (2004b - this issue). Sedimentation in the lake apparently has been nearly balanced by subsidence of the basin for tens of thousands of years (Bradbury et al. 2004 - this issue; Colman et al. 2004a - this issue). Of particular importance here is the fact that Upper Klamath Lake is currently shallow (average depth about $2.5 \mathrm{~m}$ ), fresh, slightly alkaline, and hypereutrophic. The lake stratifies only briefly in the summer. Blooms of cyanobacteria (blue-green algae, mostly Aphanizomenon flosaquae) occur each summer in Upper Klamath Lake, at least in part due to excess nutrients. This cyanobacterium fixes nitrogen and can control its buoyancy to remain in the upper water column where favorable illumination conditions exist. It dominates the phytoplankton in lake for most of the summer months.

\section{Diatom ecology}

If it were not for the summer dominance of Aphanizomenon flos-aquae, the spring and fall diatom populations would likely be larger and would account for a greater proportion of algal productivity in Upper Klamath Lake. The water chemistry and $\mathrm{pH}$ of the incoming rivers (Colman et al. 2004b - this issue) are appropriate for large blooms of Aulacoseira ambigua (e.g., Gasse 1986). Phinney et al. (1959) reported large concentrations of diatoms including that genus, Asterionella formosa, and species of Stephanodiscus in the winter and spring months of 1956 and 1957. Increased winter- spring turbulence can suspend these relatively heavy diatoms. A diatom bloom that corresponded to a sharp drop in soluble silica concentrations in Upper Klamath Lake was also reported in March 1968 (Sanville et al. 1974). Nevertheless, as the Upper Klamath Lake watershed has been developed for agriculture and irrigation, and as the lake has become increasingly eutrophic, diatoms have played a progressively smaller role in lake ecology. The reduction of diatom productivity partly reflects reduced light penetration caused by the shading effects of floating 


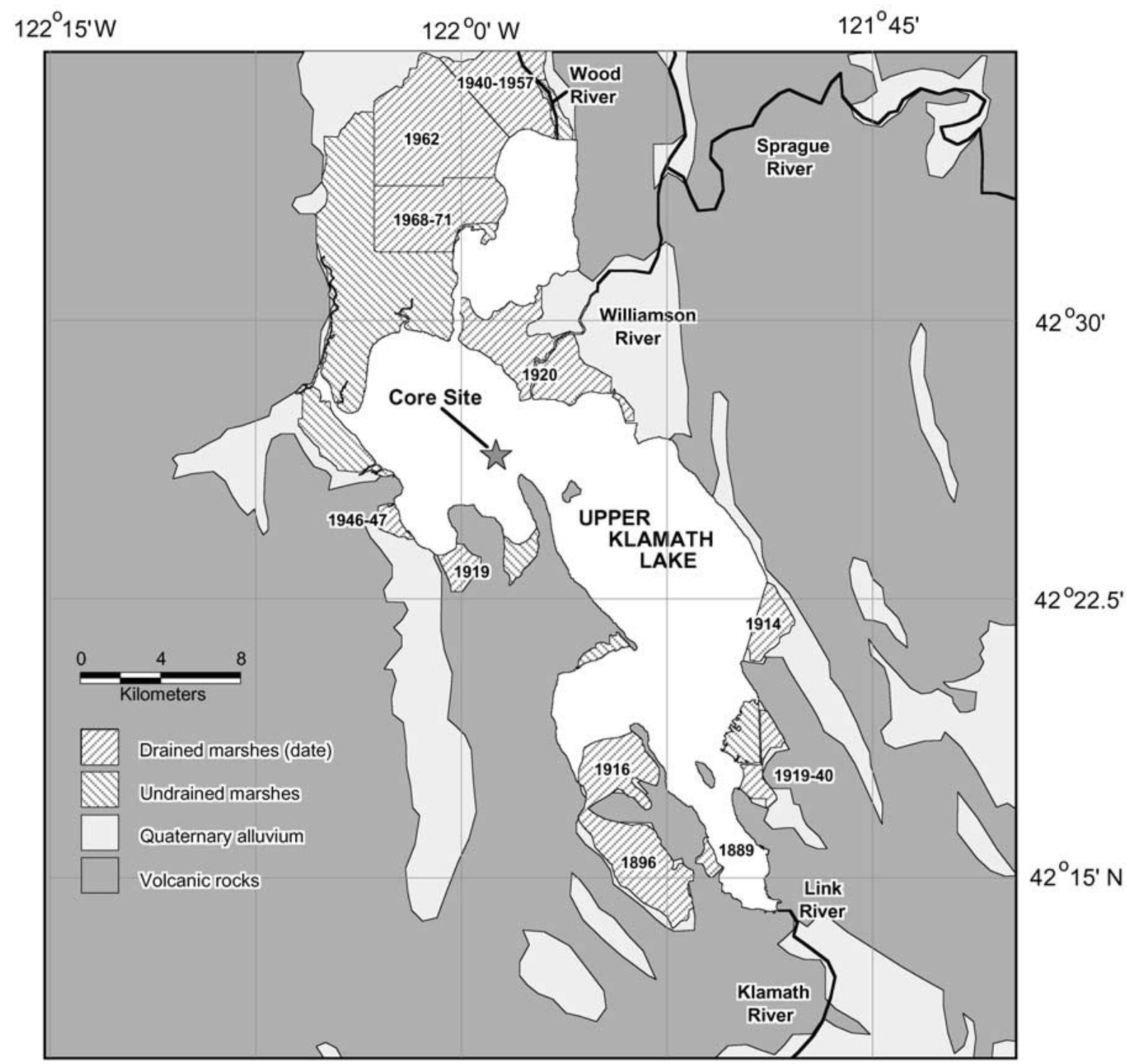

Figure 1. Index map of Upper Klamath Lake, Oregon, showing surrounding marshes (original versus present, from Snyder and Morace 1997), rivers, and core location.

cyanobacteria (Figure 4B, C of Colman et al. $2004 b$ - this issue).

Non-cyanobacterial phytoplankton in Upper Klamath Lake have been little studied and few data exist for the period before Upper Klamath Lake became hypereutrophic. Diatom analyses of curated microscope slides of Upper Klamath Lake phytoplankton, however, support observations of decreased abundance of Aulacoseira ambigua after the 1950s when Aphanizomenon flos-aquae overwhelmingly dominated the summer phytoplankton (Table 1). Consequently, today, diatom phytoplankton productivity occurs mostly in the late winter, spring and fall. Small and intermediate-sized Stephanodiscus species ( $S$. oregonicus, S. hantzschii, and S. parvus) characterize the spring bloom when nutrient loading is related to spring runoff, along with Asterionella formosa and 
Table 1. Percentage of dominant planktic and tychoplanktic diatom species in Klamath Lake.

\begin{tabular}{lrcc}
\hline Diatom/Date & 1932 & May 1951 & May 1967 \\
\hline Aulacoseira ambigua & 11 & + & + \\
Stephanodiscus oregonica & 6 & 2 & 5 \\
Stephanodiscus niagarae & 5 & 47 & 3 \\
Asterionella formosa & & 24 & + \\
Fragilaria vaucheriae & & 3 & 67 \\
Fragilaria capucina & & 9 & + \\
Staurosira and allied taxa & 62 & 5 & 2 \\
\hline
\end{tabular}

+ , less than $1 \%$. Counts by JPB from archived slides and samples.

sometimes Aulacoseira granulata, whereas Stephanodiscus niagarae appears to be the major species developing in the fall (Kann 1997).

Under natural limnological conditions, increased river flow into Upper Klamath Lake would reduce the residence time of water and nutrients in the lake - as occurs today during the spring runoff season (Figure 4B, C of Colman et al. 2004b - this issue) and promote the development of marshes along gentle gradients upstream. Marsh macrophyte vegetation utilizes and stores nutrients, thereby reducing the nutrient flux to the open-water areas of Upper Klamath Lake (Snyder and Morace 1997). Productivity of planktic diatoms would increase under such circumstances as suggested by limnological investigations in the 1950s (Phinney et al. 1959). The species composition of planktic diatoms in a less productive Upper Klamath Lake would depend upon the timing and fluxes of silica, phosphorus, and nitrogen under the control of lake circulation and climate. In all probability, however, the spring and fall diatom blooms of Stephanodiscus species would have expanded, and a summer diatom bloom consisting of Aulacoseira species ( $A$. granulata and A. ambigua) would become more prominent than at present.

\section{Settlement history and lake impacts}

Before marsh drainage, dam construction, and related hydrological manipulations, the principal lakes in the Klamath basin, including Upper Klamath Lake, were shallow, marsh-fringed (Scirpus and Typha) aquatic systems with large expanses of open water (Figure 1). The first documented entry of white men into the Klamath Basin was in 1825 , when beaver trappers explored the

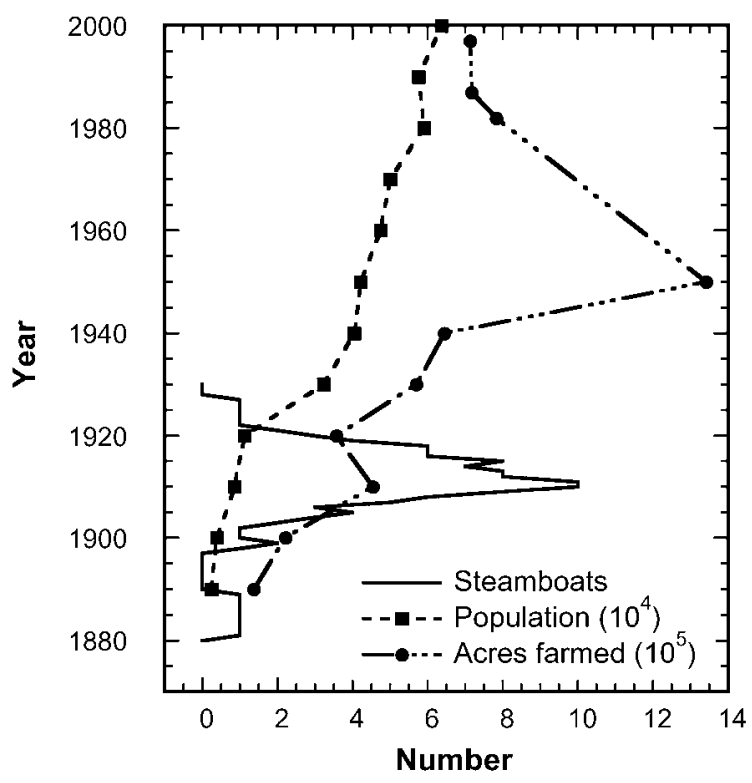

Figure 2. Selected indices of human activity in Upper Klamath Lake basin, including numbers of steam-powered water craft operating on Upper Klamath Lake, population of Klamath County, and number of acres farmed in Klamath County. Steamboat data from Drew (1974); other data from US Dept. of Commerce, Census Bureau.

area. Twenty years after Captain John C. Frémont's (1845) report of Klamath Indian boats on the lake, Upper Klamath Lake became a major part of the trade route in the basin (Bond et al. 1968). Euro-American settlers established a ferry across the Link River in 1867 (Drew 1974). Fort Klamath, at the northwestern end of the lake, had a sawmill and the settlers of the area provided farm goods transported by barges, some rigged with sails and oars. By 1870, settlers had become numerous enough to completely disrupt native American lifestyles. The Modoc War (1872-1873) effectively opened the area for even more extensive settlement. In the spring of 1881 , the first steam-powered boat operated on Upper Klamath Lake towing logs and transporting assorted cargo. By the 1890 census, Klamath County had been established and data on population and agriculture are available (Figure 2).

The relative importance of different human activities on the lake, the surrounding marshes, and the drainage basin is difficult to estimate. Steamboat and barge transportation dominated lake use in the late 19th and early 20th centuries until replaced by railroads and automobile traffic 


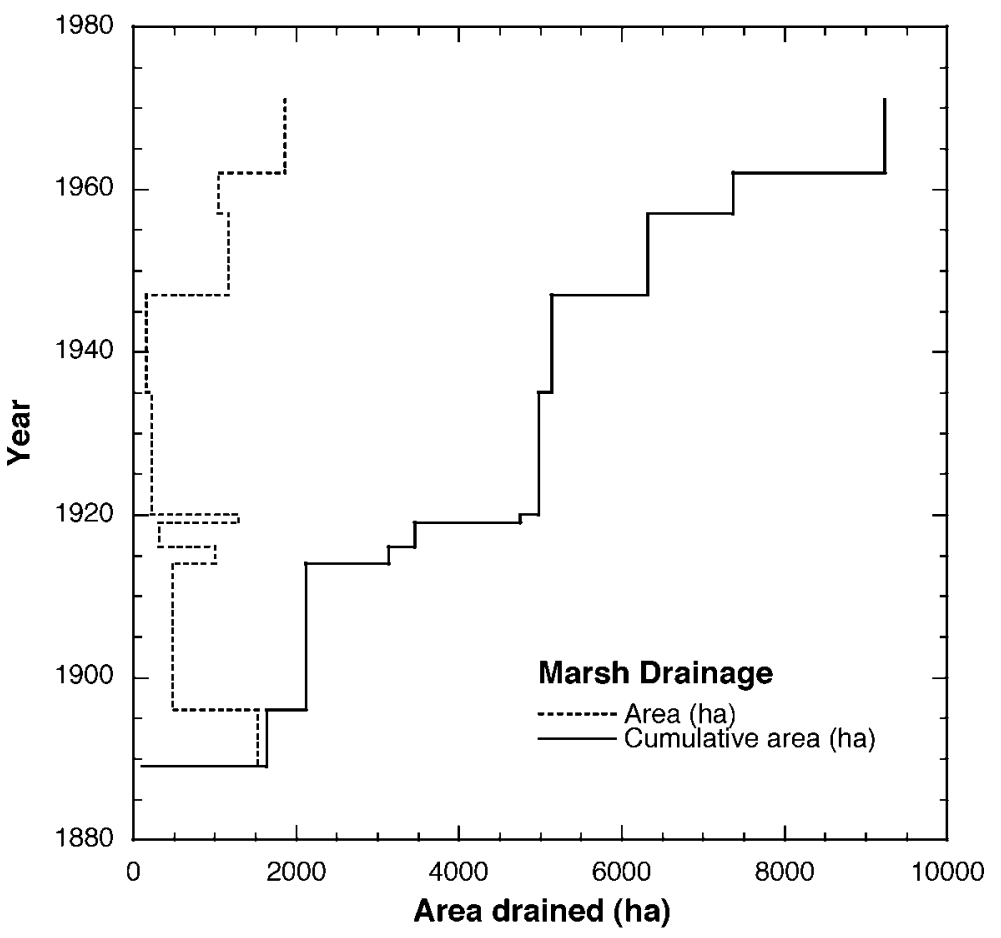

Figure 3. Historical record of marsh drainage around Upper Klamath lake (data from Snyder and Morace 1997).

(Drew 1974). Shallow draft steamboats and other craft on Upper Klamath Lake (Figure 2) serve as an index of overall human activity during this time. Boat traffic must have resuspended the diatomaceous, water- and nutrient-rich sediment in the shallow lake, although wind-driven resuspension events were probably more important.

In 1917, the rock sill between Upper Klamath Lake and its outflow through the Link River was lowered by about $1 \mathrm{~m}$, enabling water levels of Upper Klamath Lake to be manipulated for agriculture around Upper Klamath Lake (marsh drainage) and in downstream basins (irrigation). A dam constructed on the Link River in 1921 has allowed retention of peak spring flows and higher than historic water levels at some times (Bortleson and Fretwell 1993). The dam also generates power and provides water for irrigation downstream. Today, lake level fluctuates about $\pm 1 \mathrm{~m}$ around the former minimum level of the lake, which was controlled by the bedrock sill at $1262 \mathrm{~m}$ (4140 feet). Human activities in the upstream drainage basin, including timber harvest (Risley and Laenen 1998) and cattle production (Eilers et al. in press), farming (Figure 2), and road construction, must have had significant effects on the lake. Many of these activities accelerated in the 1920s. Under natural conditions, the lake was buffered from changes in the upstream watershed by the fringing marshes, which served to trap and filter sediment and water.

Conditions in Upper Klamath Lake must be sensitive to changes in the fringing marshes for proximity reasons alone. Wetland drainage began in 1889 (Figure 3), and at present, about 64\% (about $12500 \mathrm{ha}$ ) of the natural wetlands adjacent to Upper Klamath Lake have been drained for various agricultural pursuits including cattle grazing, haying, and crop cultivation (Snyder and Morace 1997). Large areas were drained at the end of the 19 th century and again in the past 40 years. During the drought of the 1930s and during World War II, wetland drainage decreased significantly (Figure 3).

Drainage of the marshes has several direct effects on the lake. First, marsh peats and organic soils are known sinks for nutrients in many environments, including Upper Klamath Lake (Gearheart et al. 1995; Snyder and Morace 1997; Boyd et al. 2002). Marsh drainage leads to decomposition of peats and organic soils, releasing nutrients to the lake (Snyder and Morace 1997; Boyd et al. 2002). 
Secondly, marshes serve as traps and temporary storage for upstream water and sediments. Some of this sediment may be remobilized and delivered to the lake through drainage ditches in the marsh. Perhaps more importantly, channelization of major streams, such as the Williamson River, through the marshes allows those streams to bypass the filter formerly provided by the marshes, delivering water and sediment directly to the lake.

\section{Methods}

\section{Coring}

In the fall of 1996, a 45-cm long gravity core (C7-A) was raised from the northwest end of Upper Klamath Lake (Figure 1) in a water depth of $2.5 \mathrm{~m}$ (core location: $42^{\circ} 26.414^{\prime} \mathrm{N}, 121^{\circ} 58.747^{\prime} \mathrm{W}$; elevation $1263 \mathrm{~m}$. The core, among others (Colman et al. $2004 \mathrm{~b}$ - this issue), was returned to the laboratory in its plastic liner, split lengthwise, and sampled.

\section{Microfossil analysis}

Diatoms were prepared by chemical oxidation of $0.5 \mathrm{ml}$ wet samples in $100{ }^{\circ} \mathrm{C}$, concentrated nitric acid, and cleaned in distilled water. Equal volume aliquots were settled on coverslips (Battarbee 1973) and mounted in naphrax $(n=1.6)$. Four hundred (minimum) valve counts were made to establish relative percentages of the dominant diatom species in the core. Shards of volcanic glass (tephra) were enumerated in standardized transects on the same slides.

Pollen, charcoal, algae, and cyanobacterial akinetes were separated from the wet sediment by digestion in $10 \% \mathrm{HCl}$ and $48 \% \mathrm{HF}$ followed by $5 \% \mathrm{KOH}$, and washing in distilled water. Organic microfossil residues were stored in glycerine. Three hundred pollen grains were tallied at each level. Pediastrum, charcoal fragments, and akinetes of Aphanizomenon flos-aquae were enumerated separately from the pollen sum.

\section{Sediment magnetic analysis}

We used a combination of reflected-light petrographic and magnetic methods to determine the types, amounts, and origins of magnetic minerals. Magnetic property measurements included: (a) isothermal remnant magnetization (IRM acquired at 0.3 Tesla (T)), a measure primarily of magnetite content; (b) hard isothermal remnant magnetization $\left(\mathrm{HIRM}=\left[\mathrm{IRM}_{1.2 \mathrm{~T}}-\mathrm{IRM}_{0.3 \mathrm{~T}}\right] / 2\right)$, a measure of the hematite content; (c) the $S$ parameter $\left(S=\mathrm{IRM}_{0.3 \mathrm{~T}} / \mathrm{IRM}_{1.2 \mathrm{~T}}\right)$ that expresses relative magnetite and hematite contents; and (d) the ratio of anhysteretic remnant magnetization (ARM) to IRM $M_{0.3 \mathrm{~T}}$ that reflects magnetic grain size of magnetite (Thompson and Oldfield 1985). $\mathrm{ARM} \mathrm{IRM}_{0.3 \mathrm{~T}}$ increases as magnetic grain size of magnetite decreases, and it is particularly sensitive to single domain (SD) and small pseudo-single domain (PSD) grain sizes in rocks and sediments in which magnetite is the dominant magnetic mineral.

\section{Core chronology}

A combination of tephrochronology and radiogenic methods $\left({ }^{14} \mathrm{C},{ }^{210} \mathrm{~Pb},{ }^{137} \mathrm{Cs}\right)$ has been used to date the sediments in a variety of cores from Upper Klamath Lake (Colman et al. 2004a - this issue). ${ }^{210} \mathrm{~Pb}$ data suggest that the uppermost sediments are mixed at most sites (Martin and Rice 1981; Eilers et al. in press; Colman et al. 2004a - this issue), probably primarily by wave action in this broad, shallow lake (Laenen and LeTourneau 1996). At the core site discussed here, the ${ }^{210} \mathrm{~Pb}$ data indicate the presence of excess ${ }^{210} \mathrm{~Pb}$ (above background) to a depth of about $25 \mathrm{~cm}$. The data for the upper $8 \mathrm{~cm}$ are nearly constant, suggesting a mixed layer to this depth. The data between 8 and $25 \mathrm{~cm}$ suggest a relatively uniform sedimentation rate, averaging $0.172 \mathrm{~cm} / \mathrm{yr}$ (Figure 4A). A prominent increase in the diatom Aulacoseira ambigua occurs near the base of core C7A $(44 \mathrm{~cm})$; this diatom horizon appears to be a synchronous event throughout Upper Klamath Lake, dated to about 260 years ago (Colman et al. 2004a - this issue). The average sedimentation rate of $0.172 \mathrm{~cm} /$ year was applied to all data in this paper to yield age estimates for past events. The 8 -cm mixed zone corresponds to about 45 years at a sedimentation rate of $0.172 \mathrm{~cm} /$ year, although it is possible that the uppermost $8 \mathrm{~cm}$ accumulated somewhat faster than the material below. As a result of mixing, markers of stratigraphic events have been blurred 

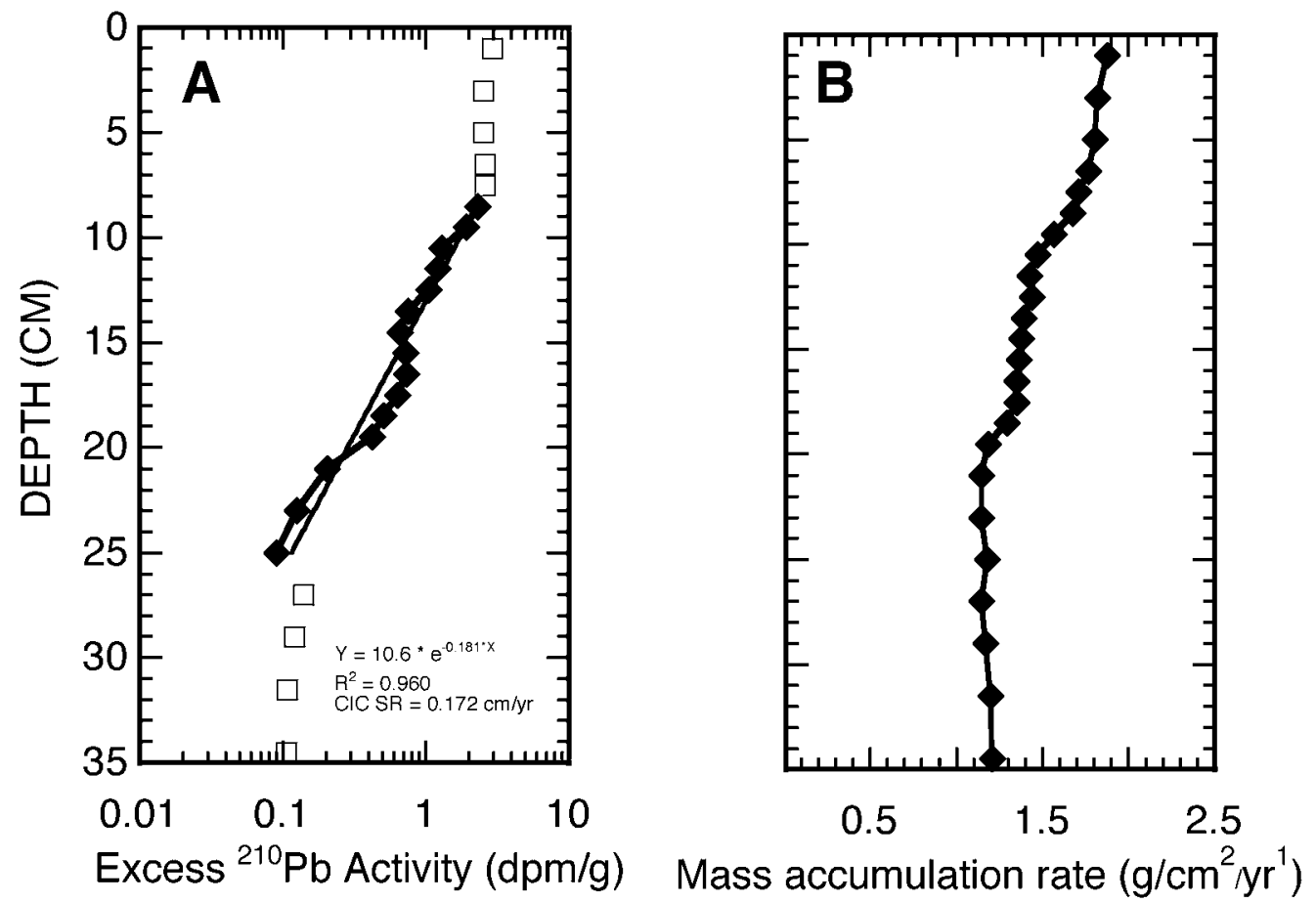

Figure 4. Plot of ${ }^{210} \mathrm{~Pb}$ measurements (A) and mass accumulation rates (B) with depth for core $\mathrm{C} 7 \mathrm{~B}$, companion core to $\mathrm{C} 7 \mathrm{~A}$. ${ }^{210} \mathrm{~Pb}$ methods and discussion are in Colman et al. (2004a - this issue). Solid symbols in (A) used in calculation of sedimentation rate (SR) using constant-initial-concentration (CIC) assumptions; this SR was used to calculate mass accumulation rates in (B).

in the core and their magnitudes significantly smoothed.

Interpretation of the ${ }^{210} \mathrm{~Pb}$ data is complex, so that age estimates discussed here carry probably uncertainties of $\pm 10-20$ years (Colman et al. $2004 \mathrm{a}$ - this issue). Our interpretation of a constant sedimentation (increase in thickness) rate for core C7 is conservative; other interpretations are possible, including ones in which the sedimentation rate increases in the upper part of the core. Using density measurements along with the sedimentation rate of $0.172 \mathrm{~cm} /$ year, we also calculated mass accumulation rates (Figure 4B). These calculations indicate that mass accumulation rates have increased, beginning at about $18 \mathrm{~cm}$ (ca. 1890). Increased 20th century mass accumulation rates were also reported by Eilers et al. (in press). The higher densities in the upper part of the core (in contrast to the usual trend related to compaction) suggests an increased lithogenic component, consistent with the $\mathrm{Ti}$ and $\mathrm{Al}$ measurements of Eilers et al. (in press) and sediment magnetic properties discussed later.

\section{Interpretation of results}

\section{Magnetic properties}

Magnetite and hematite occur mainly as grains within volcanic rock fragments; more rarely, magnetite is found within tephra shards. Because of its association with hematite and ilmenite that were incorporated in the magnetite during initial cooling, the magnetite in the core (typically $10-80 \mu \mathrm{m}$ ) represents detrital particles derived from igneous rocks. Hematite also occurs in extremely finegrained forms that redden pre-depositionally oxidized volcanic rock fragments. The magnetite and other $\mathrm{Fe}-\mathrm{Ti}$ oxides in the core are unaffected by post-depositional alteration. There is no evidence for the presence of anthropogenic magnetic minerals that are produced by industrial activity and that may be transported as airborne particles.

These observations enable the interpretation of magnetic property profiles in terms of variations in detrital magnetite and hematite contents that reflect changes in the input of lithogenic sediment. 

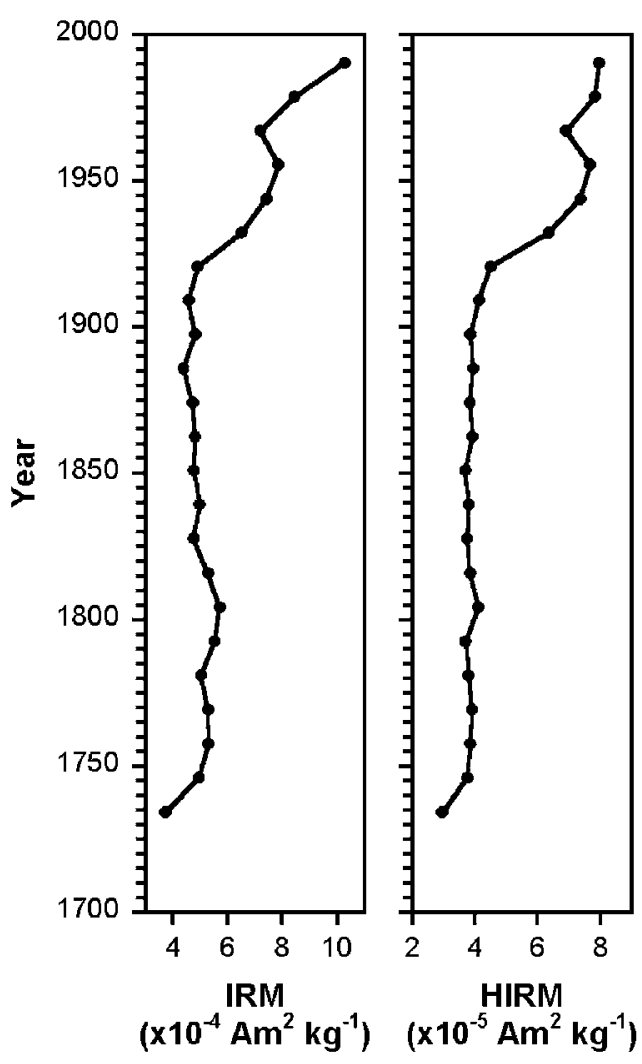

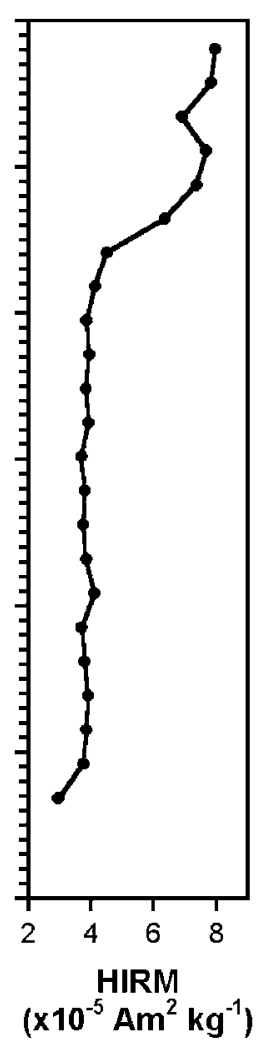

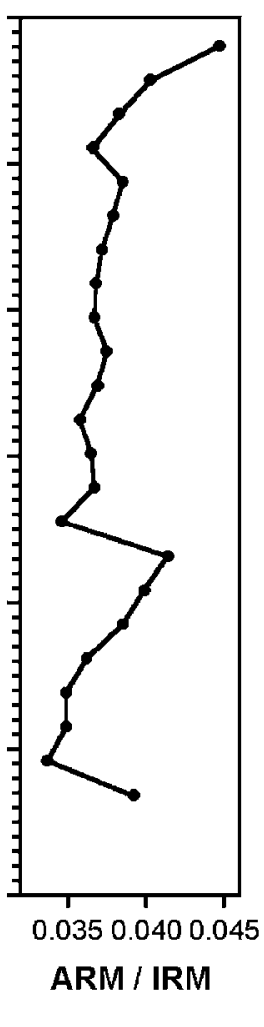

Figure 5. Sediment magnetic parameters versus age in core C7A. See text for explanation of magnetic-property acronyms.

Magnetite and hematite are very low through most of the core but increase gradually after $1920(12-\mathrm{cm}$ depth) (Figure 5), corresponding with a change from gray, relatively diatomaceous sediment to brown, relatively lithogenic sediment. Magnetite and hematite contents vary together closely, as expected for source sediments in which these minerals are related by common initial origin (primary cooling of lava), pre-depositional alteration (magnetite oxidation to hematite), and specific gravity.

Both magnetite and hematite contents increased strongly beginning about 1920, when major wetland drainage of Williamson River North tract began (Figures 1 and 3). This close correspondence suggests that the increase in magnetic minerals resulted from wetland drainage and river channelization, either directly from marsh drainage ditches or indirectly from farther upstream, through channelized rivers (especially the lower Williamson) that newly bypassed the marshes. Timber harvest, which also increased in the 1920s (Risley and Laenen 1998) may have been important in this regard. The Williamson River is the major drainage into Upper Klamath Lake and enters the lake less than $4 \mathrm{~km}$ from the coring site (Figure 1). On the basis of this proximity, it seems likely that sediments in the core would be more sensitive to changes in sediment from the Williamson River than from other, more distant and smaller, drainages around the margins of the lake. Since about 1950, the increase in absolute magnetite content corresponded to slightly increasing amounts of magnetite relative to hematite ( $S$ values increase) and minor decreases in magnetite grain size (ARM/ IRM increases) (Figure 5). These changes in uppermost $8 \mathrm{~cm}$ (since about 1950), although subtle, are consistent with slightly more input of 'fresh' sediment (unaltered volcanic rock fragments) compared with the detrital sediment deposited earlier. The suggested increase in fresh detrital sediment input may be related to human activity in the 
Williamson-Sprague river catchments, including road building, clearing, and development, as well as drainage for agriculture.

\section{Diatoms}

Diatom assemblages of the past 260 years represented by core C7-A were characterized by planktic species with minor percentage variations (Figure 6). Only at the bottom of the core (ca. 265 years ago) did benthic diatoms, mostly Staurosira consturens varieties, dominate to suggest low lake levels and nearby marsh habitats. This dominance of benthic diatoms correlates with a similar assemblage recorded at Howard Bay (Bradbury et al. 2004 - this issue) and implies low lake levels throughout Upper Klamath Lake, perhaps in response to drought conditions recorded by tree rings around 1740 (Keen 1937). The appearance of Aulacoseira ambigua, a planktic diatom often blooming during the summer months, documents increasing moisture, greater flow-through, and marginally higher lake levels after 1750 . The maximum percentages of Aulacoseira ambigua developed during the first quarter of the 19th century when tree rings again suggest persistent favorable moisture conditions (Keen 1937). The 'Big Oregon Drought' of 1839-1850 may have been responsible for the reduction of Aulacoseira ambigua afterwards.

The second half of the 19th and the beginning of the 20th centuries witnessed the appearance of several planktic diatom species indicative of increased productivity of Upper Klamath Lake. The first to appear was Stephanodiscus minutulus between 1860 and 1870 (Figure 6). This taxon frequently becomes abundant in the spring diatom bloom of lakes enriched in phosphorus (Bradbury 1975, 1988). The arrival of Stephanodiscus minutulus coincides with the extensive settlement of Upper Klamath Lake. Farming and lumbering were the principal economies and barge traffic transported goods across and along the lake.

By about 1910, Stephanodiscus hantzschii, S. parvus and Fragilaria capucina appeared. Both diatoms also indicate nutrient enrichment and Fragilaria capucina, an opportunistically planktic ('tychoplanktic') species, suggests that nutrient levels became sufficient to support it in the open water. Finally, about 1930, Asterionella formosa increased to become a minor, but significant part of the diatom plankton in Upper Klamath Lake. Asterionella formosa may indicate increased Si/P supply ratios in the lake (Tilman et al. 1982). The Si/P supply ratio may have changed as a result of significant phosphorus consumption by cyanobacteria and by influx of silicon-rich water from direct marsh drainage to the lake.

Overall, the changes in the stratigraphy of diatom assemblages in core C7-A were subtle (Figure 6), which is consistent with modest changes documented by Eilers et al. (in press). Throughout the past 260 years, Upper Klamath Lake has always been shallow and eutrophic. The diatoms appearing after the mid 19th century, although indicative of increased nutrient levels and changes in the supply ratios of the essential limiting nutrients $\mathrm{Si}$ and $\mathrm{P}$, did not become abundant. Most of the common benthic diatoms in the lake, particularly species of Fragilaria, Staurosira, and Staurosirella, remained at fairly stable abundance as did the common planktic species of Stephanodiscus and Aulacoseira. Nevertheless, the timing of the minor increases of planktic diatoms indicating nutrient enrichment coincides with the settlement patterns of the basin beginning in the late 1860 s and intensifying after 1900 . The impacts of settlement on the lake, particularly land clearance and increased nutrient loading by erosive runoff as well as sediment and nutrient resuspension by boat traffic, were sufficient to promote the increases of the nutrient-loving diatom taxa. Their minor role in the overall diatom productivity of the lake probably can be attributed to increases in other phytoplankton, especially cyanobacteria, which could out-compete diatoms for light and nutrients.

\section{Pollen and algal remains}

The pollen record for the past 260 years at Upper Klamath Lake (Figure 7) shows an unexpected uniformity. There seems to be no pollen signature of droughts known to have taken place during that time (Keen 1937) nor of vegetation modification by settlement, as for example increases in agricultural weeds after 1860 when farming became an important land use strategy. An increase in Juniperus pollen during the past 40 years could reflect opening of forest habitats by logging or urban development, but the change was not great. Recent rises in 


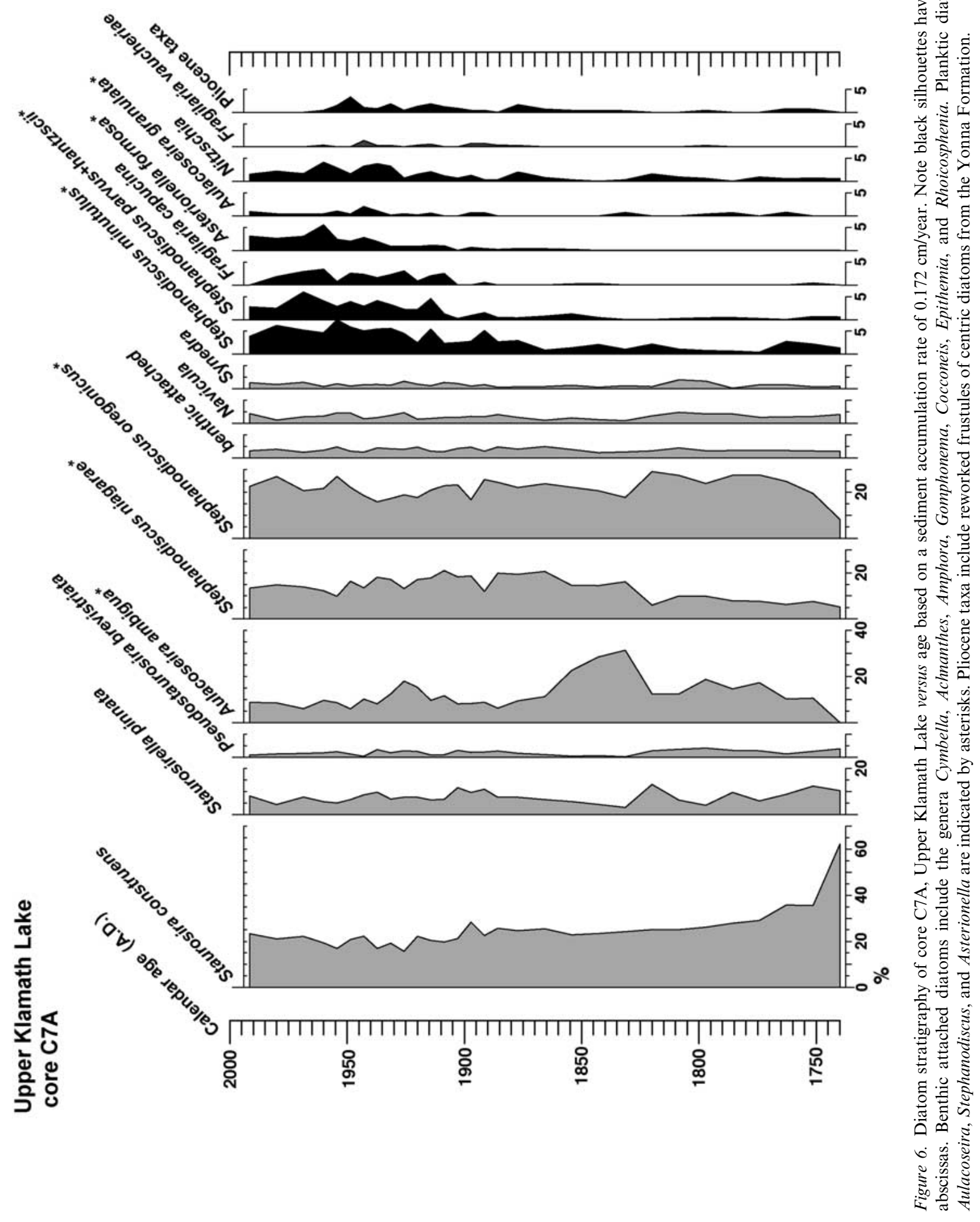




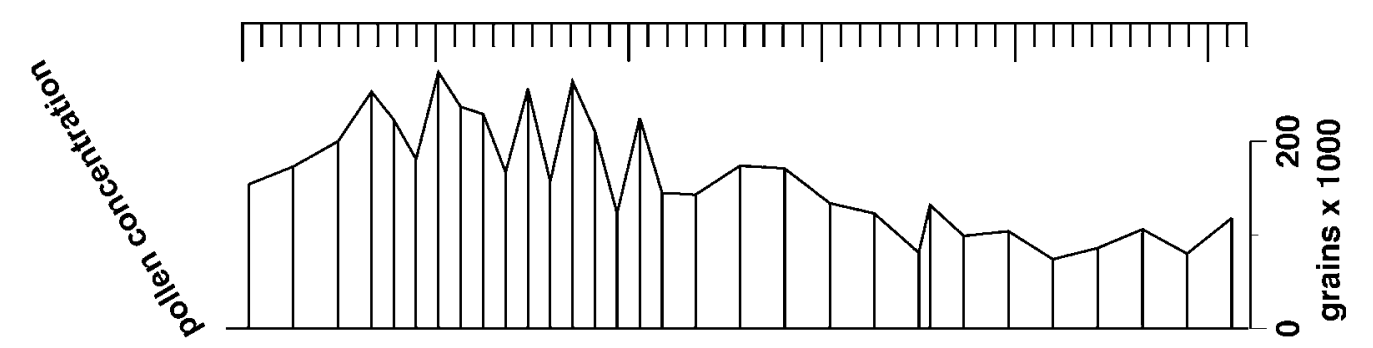

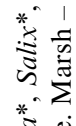

ڤ

*

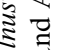

\%
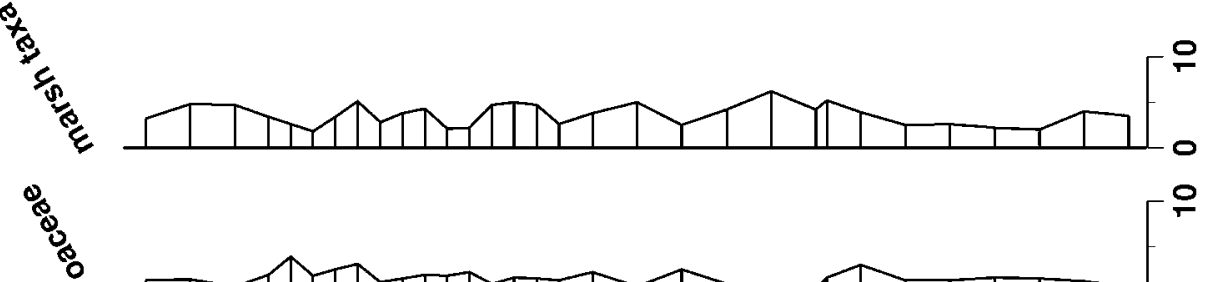

할
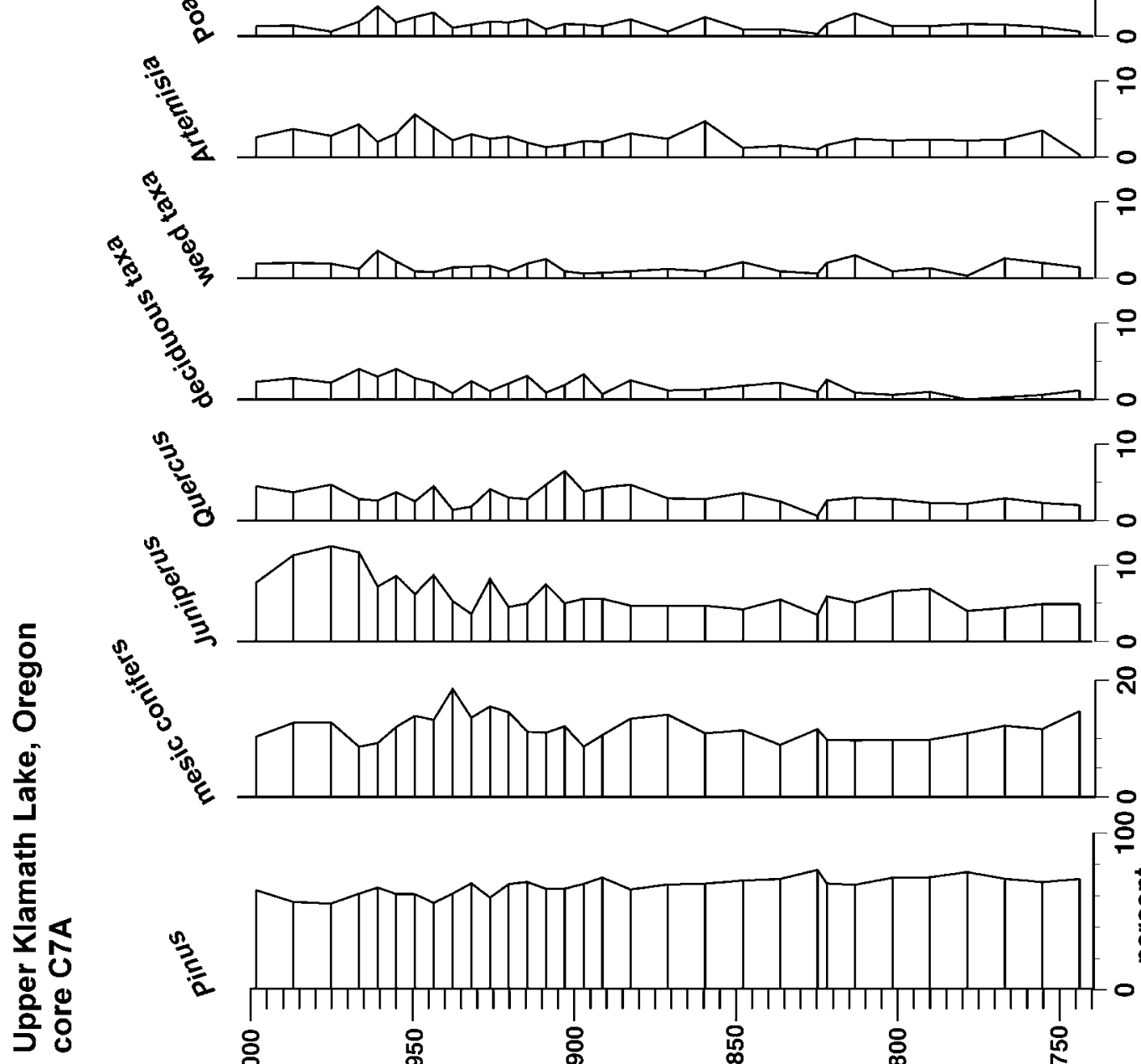

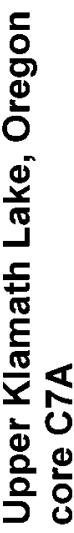

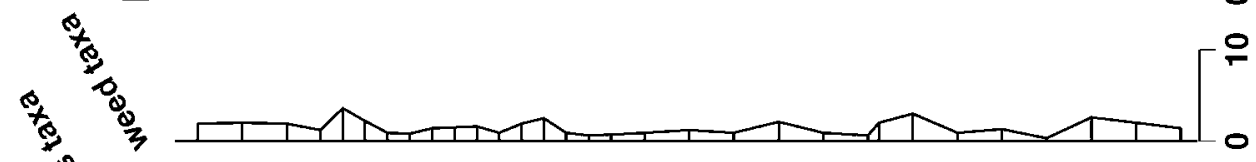

\%

o
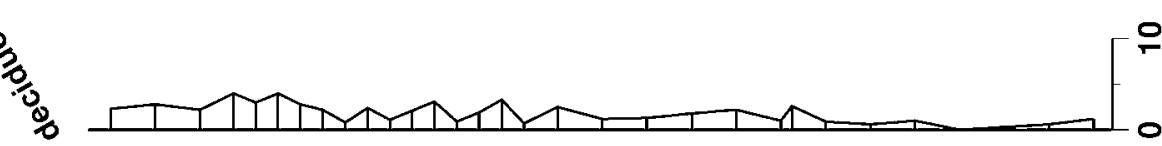

等<smiles>C1CCCCCCCCCCCC1</smiles>

$\frac{n}{2}$
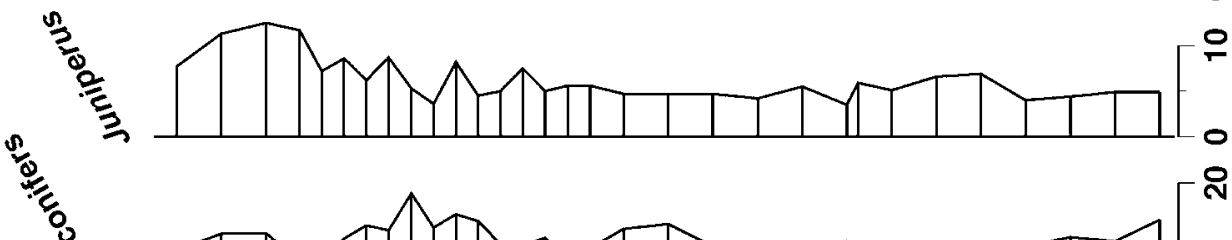

오

0

우

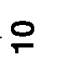

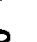

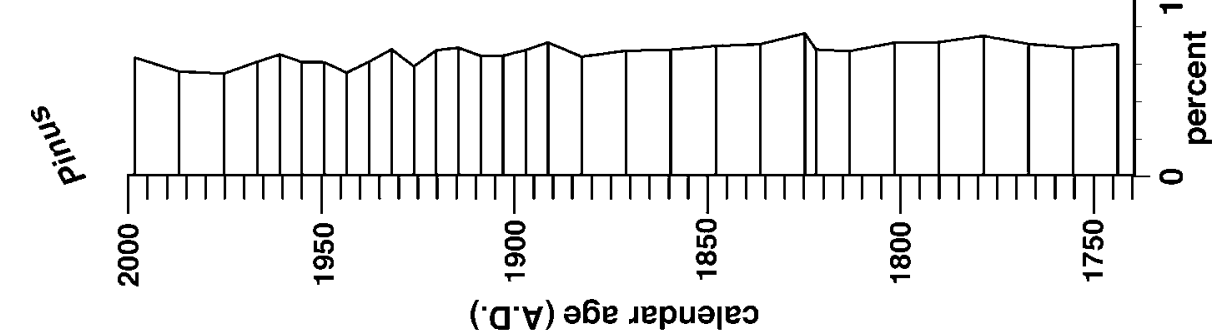

范

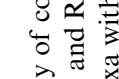

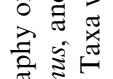

要这离

की

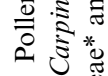

$\therefore$ 

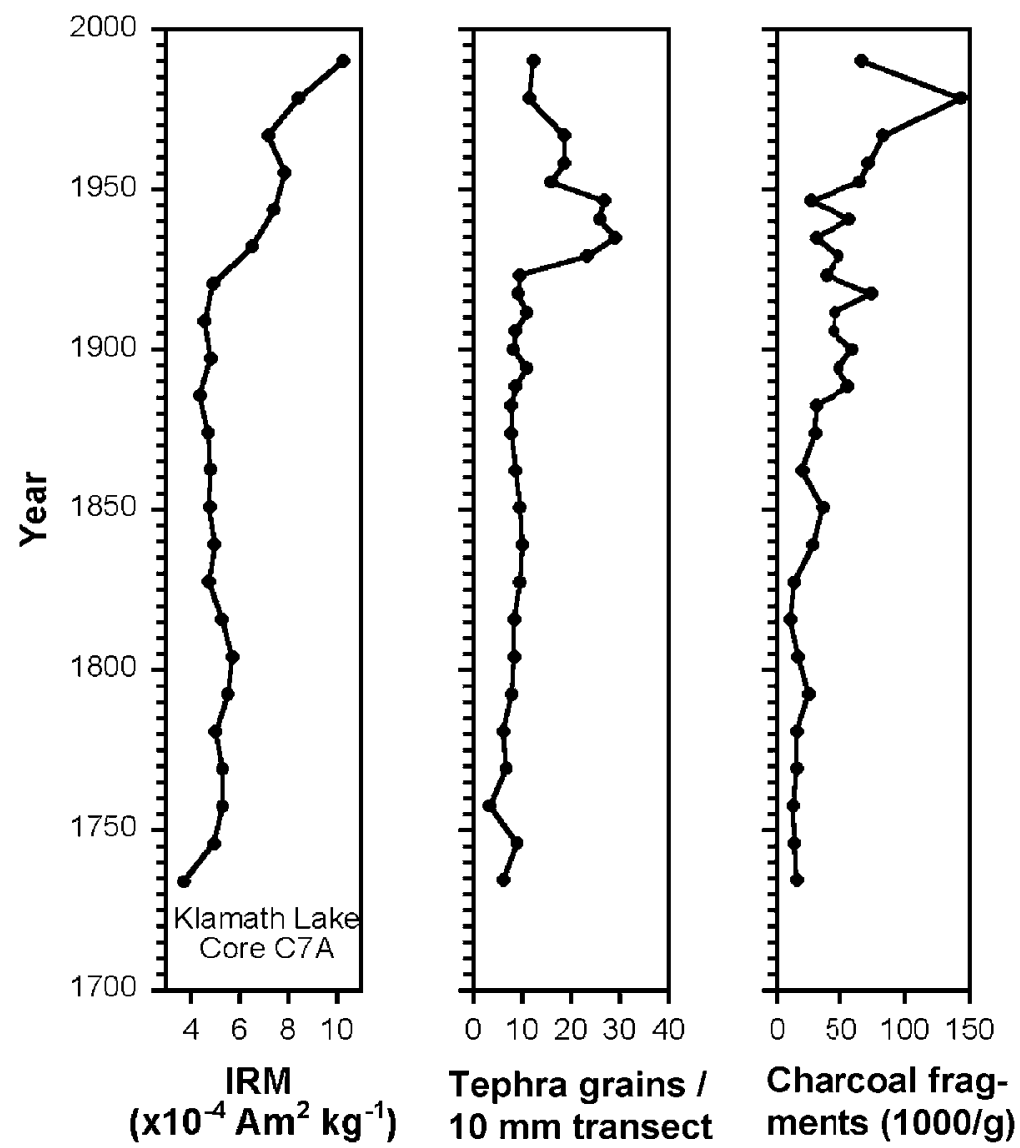
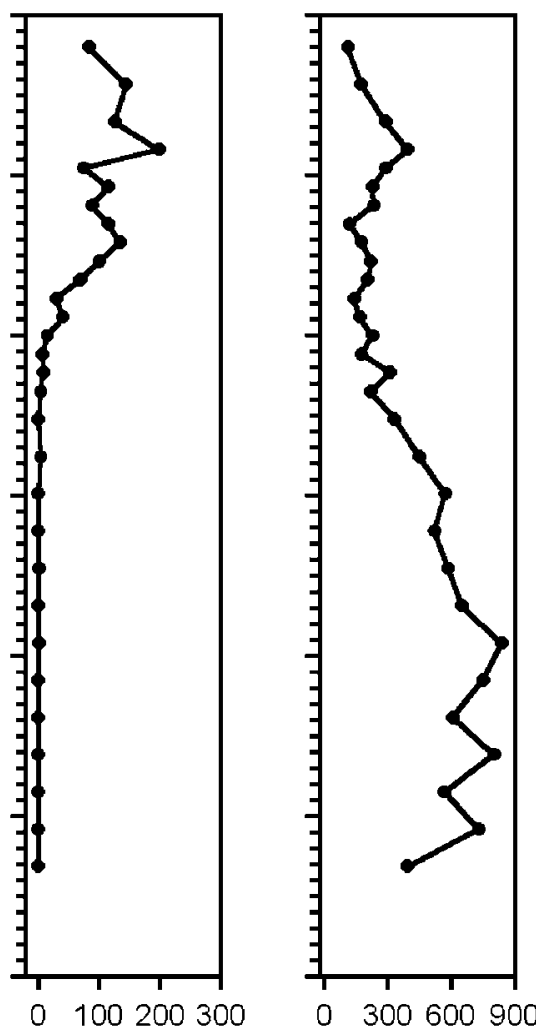

\section{Akinetes Pediastrum \\ Count / 300 pollen grains}

Figure 8. Selected parameters enumerated from core C7A versus age showing lake margin impacts and limnological change in Upper Klamath Lake.

Juniperus pollen have been observed in other parts of the Great Basin in Oregon (Miller and Rose 1995). Neither does the stratigraphy of marsh vegetation (Scirpus and Typha) seem to reflect reduction of wetland vegetation known to have taken place during the past century (Figure 3). Perhaps stratigraphic complacency is to be expected in a large lake system that receives both airfall and river-transported pollen from a wide variety of habitats dominated by conifers and upstream marsh habitats.

Pollen concentration does show a significant increase as fluctuating pulses after the end of the 19 th century. Increases in pollen concentration may reflect increases in redeposited pollen from marsh sediments as wetland habitats were ditched and drained into Upper Klamath Lake.

Non-siliceous algal remains (Pediastrum and akinetes of Aphanizomenon flos-aquae) do show stratigraphic changes that may reflect limnological and environmental changes related to human impacts (Figure 8). Pediastrum, a common green alga of eutrophic lakes, began to decrease sharply after 1850, with the appearance and later proliferation of akinetes (resting spores) of the cyanobacterium Aphanizomenon flos-aquae which document the progressive hyper-eutrophication of Upper Klamath Lake (Bortleson and Fretwell 1993; Kann 1997). The appearance of Aphanizomenon flos-aquae coincides with the beginning of EuroAmerican settlement of the Klamath basin and reaches maximum concentrations during the periods when the marginal wetlands of the lake were diked, ditched, and drained for agriculture. Eilers et al. (in press) also noted an increase in akinetes of Aphanizomenon flos-aquae and an associated decrease in the relative abundance of Pediastrum, although they showed that the total amount of 
akinetes stayed relatively constant through the settlement period. In all probability, the nutrient enrichment required to support Aphanizomenon flos-aquae results from wetland manipulation as marsh sediments are drained, dried, oxidized, fertilized, and flushed to make them suitable for agriculture (e.g., Snyder and Morace 1997). Additional nutrients were probably contributed from agricultural activities in upstream parts of the drainage basin.

The upper $12 \mathrm{~cm}$ of core C7-A are visibly more lithogenic than material below. This is consistent with similar cores having higher $\mathrm{Ti}$ and $\mathrm{Al}$ contents in their upper sections (Eilers et al. in press). In addition, the stratigraphic increases in tephra (1930-1950) and charcoal particles (1890-1950 and especially about 1980) may also relate to human impact in the Upper Klamath Lake basin (Figure 8). Wetlands are burned today, and the high charcoal peaks after 1960 may reflect local burning associated with continued lake margin development (Figure 3) and (or) upstream forest fires - the channelized Williamson river would have allowed efficient delivery of charcoal from forest fires. The tephra record is assumed to represent reworked volcanic glass shards from the Mazama or other ashes in the Upper Klamath Lake drainage. The strong increase in tephra after 1920 could reflect increased erosion along the Williamson River and redeposition of ash into the lake at that time. Alternatively or in addition, ditching and draining of wetlands such as the Williamson River North tract, where sediments rich in Mazama ash occur at shallow depths beneath the marsh surface and crop out in drainage ditches, could account for the influx of tephra shards in core C7A after 1920 when drainage activities began in this area (Snyder and Morace 1997). Lower numbers of tephra shards after 1950 may reflect more distant sources of tephra input from marsh drainage operations north of Agency Lake (Figure 1).

The increases in magnetite and hematite, beginning about 1920, correspond closely with the sharp increase in redeposited tephra (Figure 8). Nevertheless, contents of these magnetic minerals (a proxy for heavy minerals and volcanic rock fragments) do not track variations in tephra since then. Magnetite and hematite increased or remained nearly constant, while tephra influx decreased after about 1945. There is little correspondence between charcoal content and magnetic minerals other than sharing generally high values in the upper $12 \mathrm{~cm}$ of the core. This lack of correspondence suggests that burning in the catchment did not directly translate into an increase in sediment transport to the core site. The rise in akinetes precedes the increase in magnetite and hematite, implying that the input of rock detritus did not exactly match the timing of lake nutrient change. Moreover, there is no apparent relation between magnetic properties and short-term climatic events such as floods or periods of drought.

\section{Discussion}

The several proxies of limnological and environmental change in short core C7-A from Upper Klamath Lake reveal variable responses to human impacts and land use practices around the lake. The terrestrial plant pollen record mostly registers a regional signal of vegetation, and shows the least response to the local environmental changes that occurred around the lake. Only pollen concentration, which may have increased as marsh ditching and drainage washed previously deposited pollen into Upper Klamath Lake, can tentatively be interpreted as resulting from human activities.

The diatom stratigraphy documents increased eutrophication of Upper Klamath Lake by minor changes in sensitive diatoms that prosper with increased supply of phosphorus and silicon. The apparent timing of the first change (ca. 1875) suggests that the initial settlement of the Upper Klamath Lake basin, even before widespread modification of marshlands, may have changed the lake's trophic status. Further increases of Stephanodiscus species certainly reflects nutrient increases due to marsh drainage, but shortly after ca. 1900, pennate eutrophic diatoms (Fragilaria capucina and Asterionella formosa), which indicate increased supply ratios of $\mathrm{Si} / \mathrm{P}$, document the progressive importance of cyanobacteria (Aphanizomenon flos-aquae) and their successful competition for $\mathrm{P}$ in this eutrophic lake. The great abundance and competitive success of cyanobacteria probably has limited the diatom response to severe eutrophication in Upper Klamath Lake. In 
addition to nutrient utilization, the cyanobacteria can effectively compete with planktic diatoms for light as they shade productive waters beneath them.

The stratigraphy of akinetes (resting cells) of Aphanizomenon flos-aquae charts the increased trophic status of Upper Klamath Lake most directly. The chronology of the akinete increase clearly points to the increasing drainage of marginal marshlands and subsequent nutrient increases as one of the main causes for the hypereutrophic condition of Upper Klamath Lake today. Details of akinete, charcoal, magnetic parameters, and tephra records do not always match closely throughout the record of disturbance, probably because they respond to different sources and at different timescales.

Much remains to be learned about the exact character of marshland drainage and subsequent use through time, as well as the history and effects of upstream disturbance. Activities and events in upstream parts of the drainage basin of Upper Klamath Lake, such as fires, agriculture, timber harvest, and road building are significant and are likely to be transmitted downstream to the lake. As sources of lithogenic sediment, tephra, and charcoal, the fringing marshes and the upstream drainage basin are difficult to distinguish, because under natural conditions, the marshes simply serve as temporary storage for these components.

Our ability to ascribe particular limnological changes to particular human activities from the sediment record may be inherently limited. First, many of the human activities in the basin had similar histories, which are difficult to distinguish. Wind mixing of the bottom sediments of the lake limits the detail to which the chronology of limnological changes can be interpreted. Finally, the sources of many sedimentary components are not unique to areas in which specific human activities occurred, although future studies may provide better indications of the sources of sedimentary components. Despite these limitations, the stratigraphic record of impacts and changes related to human and natural processes and events indicate significant human-induced changes in the lake, and this record can be important for management strategies to maximize and sustain the many values of Upper Klamath Lake.

\section{Acknowledgements}

We thank David Nichols, Jacob Kann, and the Klamath Indian tribe for help with field logistics. C.D. McIntire, J.P. Kociolek, and H.K. Phinney provided archived slides and samples of Upper Klamath Lake phytoplankton. Helpful reviews of earlier versions of this paper were provided M.H. Bothner, W.E Dean, J.D. Halfman, J. Kann, R. Larson, and D.D. Lynch. This project was supported by the Global Change and Climate History (now Earth Surface Dynamics) Program of the US Geological Survey.

\section{References}

Battarbee R.B. 1973. A new method for the estimation of absolute microfossil numbers, with reference especially to diatoms. Limnol. Oceanogr. 18: 647-653.

Bond C.E., Hazel C.R. and Vincent D. 1968. Relations of nuisance algae to fishes in Upper Klamath Lake. Terminal Report to FWPCA, Dept. of Fisheries and Wildlife, Oregon State University, $119 \mathrm{pp}$.

Bortleson G.C. and Fretwell M.O. 1993. A review of possible causes of nutrient enrichment and decline of endangered sucker populations in Upper Klamath Lake, Oregon. US Geological Survey Water Resources Investigations Report 93-4087, 24 pp.

Boyd M., Kirk S., Wiltsey M. and Kasper B. 2002. Upper Klamath Lake Drainage Total Maximum Daily Load (TMDL) and Water Quality Management Plan (WQMP). Oregon Department of Environmental Quality, Portland, Oregon, $188 \mathrm{pp}$.

Bradbury J.P. 1975. Diatom stratigraphy and human settlement in Minnesota. Geological Society of America, Special Paper $171,74 \mathrm{pp}$.

Bradbury J.P. 1988. A climatic-limnologic model of diatom succession for paleolimnological interpretation of varved sediments at Elk Lake, Minnesota. J. Paleolim. 1: 115-131.

Bradbury J.P., Colman S.M. and Dean W.E. 2004. Limnological and climatic environments at Upper Klamath Lake, Oregon during the past 45,000 years. J. Paleolim. 31: 167-188 (this issue).

Brownell D.L. and Rinallo M.R. 1995. A selected bibliography of water related research in the Upper Klamath Basin, Oregon. US Geological Survey Open-File Report 95-285, 23 pp.

Colman S.M., Bradbury J.P., McGeehin J.P., Holmes C.W., Edginton D. and Sarna-Wojcicki A.M. 2004a. Chronology of sediment deposition in Upper Klamath Lake, Oregon. J. Paleolim. 31: 139-149 (this issue).

Colman S.M., Bradbury J.P. and Rosenbaum J.G. 2004. Paleolimnology and paleoclimate studies in Upper Klamath Lake, Oregon. J. Paleolim. 31: 129-138 (this issue).

Drew H.J. 1974. Early transportation on Klamath waterways. Klamath County Museum, Research Paper 6, 100 pp. 
Eilers J.M., Kann J., Cornett J., Moser K., Armand St.A. and Gubala C.P. (in press). Recent Paleolimnology of Upper Klamath Lake, Oregon. Hydrobiologia.

Frémont J.C. 1845. Report of the exploring expedition to the Rocky Mountains in the year 1842 and to Oregon and California in the years 1843-1844. Goles and Seaton, Washington, DC.

Gasse F. 1986. East African diatoms - taxonomy, ecological distribution. Bibliotheca Diatomol. 11: 201 pp.

Gearheart R.A., Anderson J.K., George-Forbes M., Osburn M. and Oros D. 1995. Watershed strategies for improving water quality in Upper Klamath Lake, Oregon, vol. 1, Humboldt State University, California, $41 \mathrm{pp}$.

Grayson D.K. 1976. The Nightfire Island avifauna and the Altithermal. Nevada Archaeological Survey Research Paper \# 6. University of Nevada, Reno, pp. 75-102.

Kann J. 1997. Ecology and water quality dynamics of a shallow hypereutrophic lake dominated by cyanobacteria (Aphanizomenon flos-aque). PhD dissertation, University of North Carolina, Chapel Hill, North Carolina, 110 pp.

Keen F.P. 1937. Climate cycles in eastern Oregon as indicated by tree rings. Monthly Weather Rev. 65: 175-188.

Laenen A. and LeTourneau A.P. 1996. Upper Klamath Lake nutrient loading study - Estimate of wind-induced resuspension of bed sediment during periods of low lake elevation. US Geological Survey Open-File Report 95-414, 11 pp.

Martin E.A. and Rice C.A. $1981 .{ }^{210} \mathrm{~Pb}$ geochronology and trace metal concentrations of sediments from Upper
Klamath Lake and Lake Euwana, Oregon. Northwest Sci. 55(4): 269-289.

Miller R.F. and Rose J.A. 1995. Historic expansion of Juniperus occidentalis (western juniper) in southeast Oregon. Great Basin Nat. 55: 37-45.

Phinney H.K., Peek C.A. and McLachlan M.C. 1959. A survey of the phytoplankton problems in Klamath Lake. Oregon State University, Department of Biology, mimeograph, $52 \mathrm{pp}$.

Risley J.C. and Laenen A. 1998. Upper Klamath Lake basin nutrient loading study - Assessment of historic flows in the Williamson and Sprague Rivers. US Geological Survey Water Resources Investigations Report 98-4198, 22 pp.

Sanville W.D., Powers C.F. and Gahler A.R. 1974. Sediments and sediment-water nutrient interchange in Upper Klamath Lake, Oregon. US Environmental Protection Agency Report EPA-660/3-74-015, 45 pp.

Snyder D.T. and Morace J.L. 1997. Nitrogen and phosphorus loading from drained wetlands adjacent to Upper Klamath and Agency Lakes, Oregon. US Geological Survey WaterResources Investigations Report 97-4059, $67 \mathrm{pp}$

Thompson R. and Oldfield F. 1985. Environmental Magnetism. Allen and Unwin, London, $227 \mathrm{pp}$.

Tilman D., Kilham S.S. and Kilham P. 1982. Phytoplankton community ecology: the role of limiting nutrients. Annu. Rev. Ecol. Syst. 13: 349-372. 